\title{
MINinstitute"mink
}

\section{Unionizing the Police Service: The Case of Botswana Police Service}

\author{
Prof Baakile Motshegwa \\ University of Botswana \\ Department of political and Administrative Studies \\ Private Bag UB00705, Gaborone, Botswana \\ Tel: +2673554770 Email: Motshegwa@mopipi.ub.bw \\ Fax: +2673170706
}

\author{
Accepted: Sep 16, 2013 Published: October 24, 2013 \\ Doi:10.5296/ijhrs.v3i4.4448 URL: http://dx.doi.org/10.5296/ijhrs.v3i4.4448
}

\subsection{Abstract}

Police labour relations in Botswana have been on the spotlight in recent years in Botswana. Whilst government in their Labour Policies appreciates the need for collective arrangements by employees to bargain for their conditions of service, the same favour has not been extended to the Police. It is always an issue for investigation why the Police find themselves managed by their own special Acts that explicitly prohibit them from organizing themselves for collective bargaining. This paper analyses unionization with regards to the Botswana Police Service. Whereas unionization is internationally recognized, the Police in Botswana find themselves prohibited from such action. The Trade Unions and Employers' Organisations Act, the Public Service Act and the Police Act are analysed in order to find harmony amongst these pieces of legislation. It also draws lessons from other Police Services in Southern Africa to get an international experience.

\subsection{Introduction}

Recently, Police Labour relations have been a source of fascination to many labour relations experts. It is a subject that conjures strong emotions and great controversy. Police unionisation has its own share of proponents on both sides of the fence. On the one hand, there is strong conviction that the Police should be silent and everything will happen accordingly. There is also a strong alternative voice that advocates for their involvement in the running of their affairs. The former league of proponents would seem to have not evolved from the unitary perspective of labour relations. This perspective as Salamon (2000) has noted, believes that employees share the same interests and values as their employer. The perspective, he notes, assumes that management's prerogative is legitimate, rational and accepted. In this view, any opposition whether formal or informal, internal or external, is seen as irrational. Salamon (2000) goes further to explain that unitarist managers perceive trade unions as an intrusion which competes for the loyalty of employees. Trade Unions are therefore seen as little more than a political power vehicle used by a militant minority. 
Those who advocate for the police to unionize are consistent with the realistic pluralistic view. This view, as Armstrong (2006) has noted, appreciates that organisations contain a number of interest groups and that the interests of employers and employees do not necessarily coincide. Salamon (2000) is in agreement and cites Fox (1973) who asserts that organisations are in a permanent state of dynamic tension that needs to be managed in the interests of a viable collaborative structure. Hall et al. (2002) still consistent with the pluralistic view, advice that organisations should be conscious to the fact that all jobs have the potential to be alienating, making employees indifferent or hostile to both the job and to the management. This type of alienation is counterproductive they note, and should incorporate Trade Unions as productive 'shock absorbers'. To the pluralists, Trade Unions do not, of themselves, cause the conflict within organizations as Unitarists propose but,

simply provide a highly organized and continuous form of expression for sectional interests...... 'Salamon (2000: 8)

In the light of the above, cognizant of the fact that the management of human resources is taking a pluralist approach of late, it is clear that Trade Unions have their space in today's management of Human Resources. It is therefore important at this point, to really understand what they are in order to get a perspective why certain sectors of the economy still view them with disdain.

\subsection{Methodology}

The methodology used for this study is qualitative which has mainly focused on the use of secondary data. Secondary data is data that already exists and does not have to be collected by the researcher (Punch 2005, Cavana, Delahaye and Sekaran 2001). Tharenou, Donohue and Copper (2007) have listed certain types of documents that can be used in secondary data analysis and amongst these are: company annual reports, formal charters and legal documents, policies on rules and procedures, human resource management policies and others. The advantages if using secondary data are that it is cost effective, easily accessible, and it saves a lot of time on data collection (Malhotra et al.2006).

\subsection{Trade Unions}

Hall et al. (2002) point out that the trade union movement started in the $19^{\text {th }}$ century in response to the poor pay levels and working conditions associated with early industrialization. Since then, the movement has established itself in relevance and has taken centre stage in employee relations.

A Trade Union is defined by $\mathrm{Nel}$ (1997) as a continuing permanent organization created by the workers to protect themselves at work, improve their conditions of work through collective bargaining and to provide a means of expression for their views on matters of society". Armstrong (2006) explains why workers need to protect themselves. He points out that even though all employment relationships are based on the contract of employment, the contract is never between equals. Employers, he asserts, are always in a stronger position to dictate the terms of the relationship. Armstrong (2006) cites Freeman and Medoff (1984) who appreciate that in this unbalanced power, Trade Unions are able to bring actual and desired 
conditions together.

The definition of Trade Unions has been widened to appreciate that they transcend economic lines. Salamon (2000) affirms that Trade Unions are much more than economic organizations. He proposes that they do not just negotiate pay and conditions of employment. Salamon believes Trade Unions are economic, social and political entities. In the final analysis, Armstrong (2006) is of the view that Trade Unions exist to remind management that from time to time there will be an alternative view on key issues affecting employees.

The main point really is not what Trade Unions are but what value they add to those who are members. Salamon (2000) aptly summarises the key functions in the following illustration,

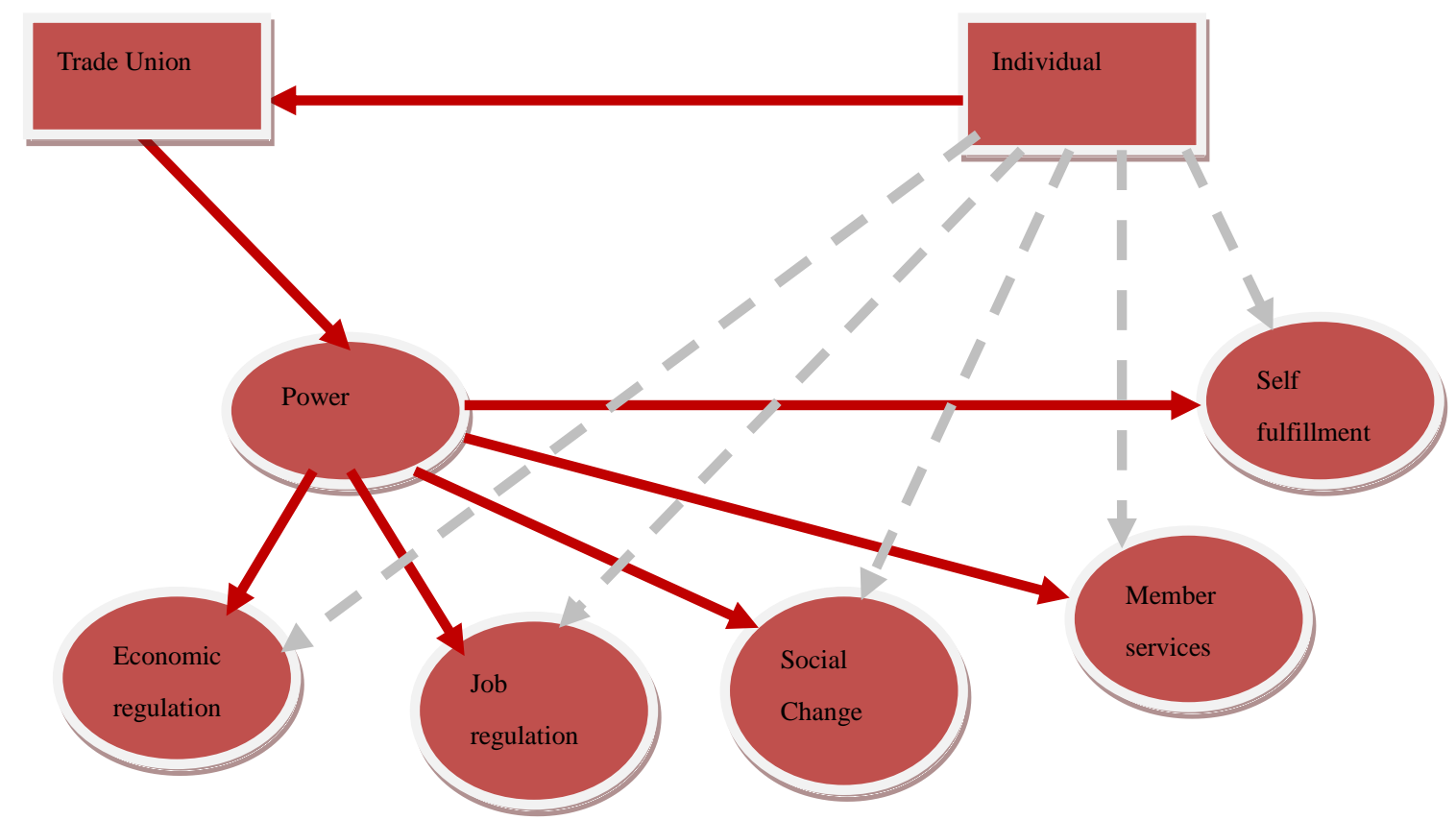

Figure 1 Key functions of a trade union. Adopted from Salamon, (2000)

Salamon's illustration summarizes that Trade Unions come with the power to protect their members by providing a collective strength against the employer, maximizing the wages and employment of their members and establish a job rule making system which protects members from arbitrary management decisions and allows for decision making. Trade Unions also exist to express the social cohesion, aspirations or political ideologies of their membership. de Silva (1996) is in agreement with Salamon that the collective voice ensures that both parties share the rule-making power in areas which, in earlier times, were regarded as management prerogatives, e.g. transfers, promotions, discipline, modernization and production norms. It can be concluded that the main focus of Trade Unions is the collectiveness of the voice to counterbalance the power of the employer.

It is important to note that Trade Unions do not exist in a vacuum, they exist within the framework of Government. It can only be relevant to investigate the legal framework in Botswana in order to form an informed opinion about the position that the Botswana Police Service has taken. 


\subsection{Legislative arrangements}

According to the International Labour Organisation (ILO), freedom of association and the right to organize and bargain collectively are fundamental human rights. However, these ILO 'guaranteed' rights do not apply automatically to the Police and the Armed Services. Botswana ratified Convention 87 and 98 of the International Labour Organisation in 1997. Of particular interest is Convention 87, Article 2 which reads,

Workers and employers, without distinction whatsoever, shall have the right to establish and, subject only to the rules of the organisation concerned, to join organisations of their own choosing without previous authorization.

The Supreme law of Botswana, the Constitution Section 3(b) bestows freedom of association as an inalienable right on all citizens. At the same time, Section (45) (1) of the Public Service Act No 30 of 2008 bestows on every public officer a right to belong to a Trade Union of his or her choice for the purpose of collective bargaining. This is a pronouncement that every individual in Botswana is covered by Law to unionize.

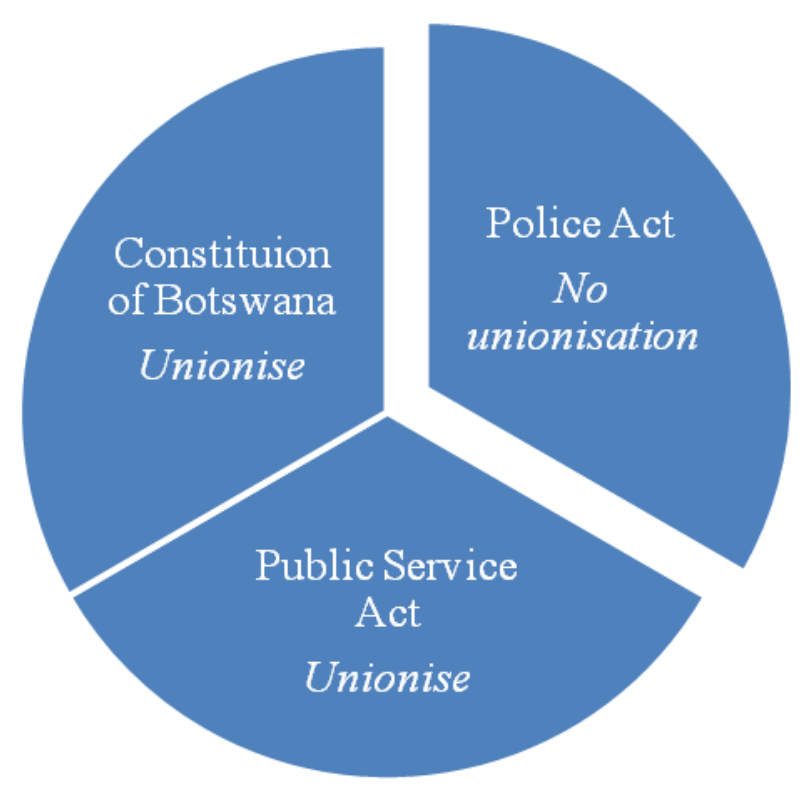

Figure 1 Constitution of Botswana, Public Service Act and the Police Act views on unionisation.

Unfortunately for the Police Officer, Article 8 (1) of the ILO standards which states thus: In exercising the rights provided for in this Convention workers and employers and their respective organisations, like other persons or organised collectivities, shall respect the law of the land, seems to be in support of the fact that the law of the land shall prevail above all has been ignored. It would have been comforting for the police officers in Botswana, if the law of the land meant the Constitution and the Public Service Act, which as noted above allow freedom of association. Even so, the Public Service Act also explicitly precludes police officers as civil servants. The Police Officer is then left to be managed by the Police Act 
which seems to have been informed by Convention 87 Article 9 (1) which says

the extent to which the guarantees provided for in this Convention shall apply to the armed forces and the police shall be determined by national laws or regulations and 9 (2) which states that

In accordance with the principle set forth in paragraph 8 of Article 19 of the Constitution of the International Labour Organisation the ratification of this Convention by any Member shall not be deemed to affect any existing law, award, custom or agreement in virtue of which members of the armed forces or the police enjoy any right guaranteed by this Convention.

Therefore, the Police Act, Section 24 (2) directs that;

a police officer shall not be or become a member of any trade union; or any body or association affiliated to a trade union; any body or association the object of which or one of the objects of which is to control or influence conditions of employment in any trade or profession or anybody or association which includes in its objects the control or influence of the pay, pensions, conditions of service or loyalty of the service".

Sub Section 3 is explicit to say that any police officer who contravenes the above Section shall be guilty of an offence against discipline and in addition to any other penalty which may be imposed, may be dismissed from the police service. This is the law of Botswana that governs police officers and it is explicit that they will not be allowed to unionize.

Police unionisation is so contentious that even management at the highest level are the greatest critic of a move in that direction. The Mmegi Newspaper of August 2009 noted that at $a$ three-day symposium, organised by the Police and Prison Civil Rights Union (POPCRU) of South Africa and Botswana Public Employees Union (BOPEU), Deputy Commissioner of Botswana Police responsible for support services told the gathering that it is impossible for the police to unionize. He said that the police wield enormous power because they are in control of arms and therefore they can hold the nation at ransom if they want. He was so adamant in this position that he even went further to say that policing is a vocation and any officer who disagrees with the working conditions should just resign and join other professions. Swanson et al. (2005) noted the International Association of Chiefs of Police that concluded that Police Unions could accomplish nothing. In their paper for the African Security Review Marks (2002: 3) quotes the Head of Legal Services of the Namibian Police Service who stated:

"The current system works well particularly because the force is so small. We do not need external regulation".

The main issue then is, based on what the Police stand to gain from a collective arrangement like a Union, is the legislation not prejudicing them. If so, what compensates for this prejudice? In order to understand this contentious issue, it would serve this paper well to understand the reasons advanced why they should not unionize. In order to do this a deliberate effort is taken to benchmark with other countries in Southern Africa to understand 
their collective arrangements.

2013, Vol. 3, No. 4

\subsection{Benchmarks with Southern African countries}

Police unions are generally shunned in the Southern African region. They are seen, as Marks (2002) has noted, as troublesome and a threat to professionalism. In his readings Burpo (1977) has also made the same findings as Marks that Unions compromise the neutrality of officers, negate professionalization and politicize otherwise non partisan organizations, like the Botswana Police Service. This might not be a good point because Statutes as noted above provide for unionisation and the illegality is only because the Police themselves have made it so through their own Acts. But what is it really that the Police are guarding against by including in their Acts, clauses that criminalize unionisation and how come other Police organisations have been liberal enough to allow unionisation?

Lesotho, Swaziland and Namibia have arrangements that prohibit unionisation of their Police Services. Marks (2002) noted that police acts in Southern Africa explicitly exclude their police officers from unionizing. Examples of these are the Lesotho Mounted Police Service Police Act No. 7 of 1998, the Labour Relations Act No. 6 of 1992 of Namibia and The Industrial Relations Act of 2000 in Swaziland and the Police Act of Botswana.

The belief in these Police Services is that management retains the prerogative to operate according to the internal police legislation. This means that grievances are dealt with through the rank and file. If the grievance is serious, it will be taken to the courts of the country. This has happened in Botswana where Police officers have taken the organization to court against transfers, promotions and in some cases overruling even the internal disciplinary process.

The only collective bargaining arrangement in these Police Services is the Police Association. This is exemplified by Section 49 of the Botswana Police Regulations derived from Section 65 of the Police Act. According to subsection 2 The Police association is meant to

$\therefore$ enable police officers representative of the various ranks...to meet in order to consider and bring to the notice of the Commissioner their views on matters relating to the general welfare including conditions of service ...".

An extension of the Police Association different from other sister organisations in Botswana, Namibia and Swaziland is the independent Negotiating Council of the Lesotho Royal Mounted Police Service created in the Act. This is a powerful external body that approves all decisions taken by the management of the organisation. Unfortunately the Associations have been dismissed as to have no clout and of no consequence. Blair (2006) has concluded that they are more like welfare/entertainment bodies that cater for soft issues like, farewell parties, burial societies, uniform and others.

South Africa is the only country in Southern Africa that legally provides for the unionisation of their Police Service (Gall, 1997). Police Officers in that country are either members of South Africa Police Union or POPCRU (Piet, 2011). It is interesting that, even though, South Africa has taken a different stand from her counterparts in Southern Africa, Marks (2002) notes that the conduct of police unions in South Africa has reinforced the belief that the police should not be allowed to unionize. They have engaged in industrial action before.

Marks (2002) advances the following reasons that make police services, Botswana included 
wary of unions.

- The Police are 'professionals' in the security sector and consequently require military-like discipline. Belonging to a trade union would be adversative to such an inclined organisation. She notes that in Zambia, for example, if police involvement in a go-slow or strike action will be tantamount to mutiny. Halpern (1974) is in agreement with Marks and notes that police managers and supervisors view police unions as disruptive entities within highly disciplined organisations.

- According to Loader (1997) the Police are fundamental to the preservation of law, order and security. This creates a tension between them identifying with unionism and at the same time being the keepers of peace.

- The Police are viewed as state agents and membership of a Trade Union will undermine that role. Zimbabwean Police Superintendents that Marks interviewed stated: "The police are the state. How can the police strike against itself?" The tone generally is that the Police are driven by loyalty to the State and maintaining the peace. A question immediately comes to mind, what are the police in democratic countries like Botswana fostering the peace against? Is it not that the Unions in Botswana, for over 46 years (1966-2012), have not shown any aggressive behaviour that can destabilise the peace? Is it not that the 2011 nationwide strike has not shown any violent demeanour that can be accused of disturbing the peace?

- The Police generally are seen as part of the essential services and should not at any point have room to engage in strike action. As disciplined cadre of essential workers, striking would be counterproductive.

From the above one can conclude that the greatest nightmare that the Botswana Police Service shares with other sister organizations in the region is industrial action. This might come from a simplistic belief that if the police unionize, they will automatically strike. On this note, Marks (2002) advices that it is dangerous for police managers to hate unions. She asserts that if collective grievances and conditions of service are not dealt with adequately, disruptive police collective action is likely at some point. Without some representative body for the police, then there will be no collective body to resolve the ensuing dispute. This Marks (2002) advices, renders Police Agencies unstable, far more so than would be if they had Unions.

\subsection{Recommendations}

In order to fully represent all the labour relations issues of the police officer, the organisation should consider an amendment to the Botswana Police Act to allow for an Independent Council even if it is not a Trade Union, to truly cater for the police needs. As it is, for example, Section 50(1) as read with Section 53 of the Public Service Act establishes a bargaining council for the Public Service with functions that include negotiating, concluding and enforcing collective bargaining agreements between the employer and recognized public 
service unions. A confusing situation arises for the Botswana Police. Whilst the Public Service Act has at first instance excluded them as Public Servants, practice has shown that in this area they are treated as public servants. Reiner (1978) stipulates that the police are as concerned about working conditions and wages as any other employees. Maybe not allowing them to unionize is not a fair.

\subsection{Conclusion}

Police unionisation is a debatable issue that needs to be treated with the utmost care. While the advantages abound that a Union can bring to an individual police officer, there are also compelling reasons why a police service like the BPS can function out of the framework. Two heavy words, grievance and discipline compete for a balance. A democracy like of Botswana, depends largely on a Police Service that is not unionized to maintain the peace. This should not at any point be misconstrued to mean that the Police have stopped to be human beings who should enjoy the privileges enshrined in the Constitution and other Legislations that accord them the freedom to associate. It would not be farfetched to believe that they are a special people, whose nature of the job, limits or denies them enjoyment of some rights.

\section{References}

Armstrong, M. (2006), A handbook of Human Resource Management Practice. (10 ${ }^{\text {th }}$ d, $)$ London: Kogan Page Limited.

Blair, G., Dowling, J. L., \& Hoover, L. T. (2006). Police labor-management relations: Perspectives and practical solutions for implementing change, making reform, and handling crises for managers and union leaders. http://www.cops.usdoj.gov/mime/open.pdf?Item=1856, retrieved on the $17^{\text {th }}$ April 2011 .

Boxall, P., Purcell, J., \& Wright, P. (2007), The Oxford Handbook of Human Resource Management. New York: Oxford University Press.

Burpo, J. H. (1977). Pros and Cons of organized labour in the Police Services, United States, NCJ 042578.

Cavana, R. Y., Delahaye, B. L. \& Sekaran, U. ( 2001). Applied Business Research: Quantitative and Qualitative Approaches. London: Sage.

de Silva, S. (1996), Collective bargaining negotiations, [Online] Available http://www.ilo.org/public/english/dialogue/actemp/papers/1998/srscbarg.htm, (October 12, 2012).

Fleming, J., Marks, M., \& Wood, J. (2006). 'Standing on the Inside Looking Out': The Significance of Police Unions in Networks of Police Governance Australian \& New Zealand Journal of Criminology. 39(1). 71-89. http:dx.doi.org/ 10.1375/acri.39.1.71.

Gall, G. (1997). Trade unions and the ANC in the 'New' South Africa. Review of African Political Economy. 22(72). 203-218. http:dx.doi.org/10.1080/03056249708704253.

Hall, L., Taylor, S., \& Torrington, D. (2002): Human Resource Management, $5^{\text {th }}$ Edition, Harlow Pearson Education Limited.

Halpern, S. C. (1974). Police-Association and Department Leaders: The Politics of Co-Optation. Lexington, Massachusetts: D.C, Heath and Co. 
International Labour Organisation (1948). Convention 87. [Online] Available: http://www.ilocarib.org.tt/projects/cariblex/conventions_1.shtml (October 09, 2012).

Loader, I. (1997). Policing and the Social: Questions of Symbolic Power. British Journal of Sociology. 48(1): 1-18.

Piet, B. (2011). Police threaten to "go slow". [Online] Available:

http://www.mmegi.bw/index.php?sid=1\&aid=363\&dir=2011/April/Tuesday19 (October 12, 2012).

Malhotra, N., Hall, J., Shaw, M., \& Oppenheim, P. (2006). Marketing Research: An Applied Orientation. Frenchs Forest: Pearson Education Australia.

Marks, M. (2002). "Organising the blues: Police labour relations in Southern Africa" African Security Review, 11(2): 50-61. http:dx.doi.org/10.1080/10246029.2002.9628131.

Punch, K. F. (2005). Introduction to social research: Quantitative and Qualitative Approaches. London: Sage.

Purcell, B. P. (2003). Strategy and Human Resource Management, $2^{\text {nd }}$ ed. London: Palgrave Macmillan.

Reiner, R. (1978). The Blue Coated Worker: A Sociological Study of Police Unionism. London: Cambridge University Press.

Republic of Botswana: The Trade Unions and Employers' Organisations' Act. Gaborone: Government Printer.

Republic of Botswana. The Constitution of Botswana. Gaborone: Government Printer.

Republic of Botswana. The Police Act. Gaborone: Government Printer.

Republic of Botswana. The Public Service Act, 2008.Gaborone: Government Printer.

Salamon, N. (2000). Industrial Relations: Theory and Practice, $4^{\text {th }}$ edition. Essex: Pearson Education Limited.

Swanson, C. R., Territo, L., \& Taylor, R. W. (2005). Police administration: Structures, processes, and behavior. ( $6^{\text {th }}$ ed). Upper Saddle River, NJ: Pearson Prentice Hall.

Tharenou, P., Donohue, R., \& Cooper, B. (2007). Management Research Methods Melbourne: Cambridge University Press. 